\title{
Assembling iPads and mobility in two classroom settings
}

\begin{abstract}
iPads have become increasingly popular as tools for teaching in early education. With their multifaceted and interactive affordances as handheld and mobile devices, they have been ascribed great potential to change and expand on classroom practice. However, the iPad often becomes just another technology hype in education, and explanations often point to teachers' and schools' lack of technical know-how and ability to utilise the devices' affordances. In this qualitative case study, we explore how teachers organise and practise iPads in two different classrooms. Classroom observations and interviews with the teachers were conducted to enrich our knowledge about the complexities of iPad use in teaching and to strengthen the knowledge of how different settings produce different iPad practices. Using an Actor-Network Theory approach, the study suggests that iPads are not simply put into use, but enacted through fluid, heterogeneous assemblages of human and non-human actors in the classroom. The iPad's affordances, such as mobility, are performed rather than inherent qualities of the devices themselves, and the classroom becomes a mishmash of fostering and hindering mobile practices.
\end{abstract}

Keywords: Educational technology, iPads, Classroom practice, Early education, Actornetwork theory

\section{Introduction}

Since its launch, Apple's iPad has been lauded as a potentially powerful tool for teaching. With a unique set of affordances, such as portability, intuitive interface, networkability, capacity for an array of applications (apps), and large screen size (Murray \& Olcese, 2011), iPads are assumed to offer more spontaneous teaching practices compared to laptops and computer labs (Burnett, 2017; Hutchison, Beschorner, \& Schmidt-Crawford, 2012). In early education, the iPad's mobility offers possibilities for informal and formal learning activities that can occur anywhere and at any time (Sandvik, Smørdal, \& Østerud, 2012). With its intuitive and portable nature, the iPad is expected to redefine and expand classroom practice (Callaghan, 2018; Culén, Engen, Gasparini, \& Herstad, 2011; Gasparini \& Culén, 2012; Jahnke \& Kumar, 2014).

However, in many cases, the iPad has ended up like so many other technology hypes in the education sector: the object of unrealistic optimism about its effects on learning and teaching, followed by let-downs in implementation and, eventually, abandonment by teachers (Falloon, 2013; Gasparini \& Culén, 2012; Guðmundsdóttir, Dalaaker, Egeberg, Hatlevik, \& Tømte, 2014). The potential for educational change ascribed to mobile devices has yet to be fulfilled, and teachers 
have been criticised for using such devices merely to supplement and reproduce traditional teaching methods (Flewitt, Messer, \& Kucirkova, 2015; Helleve, 2013; Kongsgården \& Krumsvik 2016). In this paper, we therefore explore situated processes of iPad integration in classrooms to unpack how different settings produce different practices.

The iPad is usually framed in didactical models to enrich learning experiences (Falloon, 2013; Fisher, Lucas, \& Galstyan 2013; Jahnke et al., 2017) and to improve learning outcomes (Haßler, Major, \& Hennessy, 2016; Neumann, 2018; Roschelle et al., 2010). Failed implementations of digital devices in the classroom are often explained by a lack of alignment with pedagogy. The focus has shifted from the technologies themselves to teachers' knowledge, skills, and attitudes towards technology, and to the school culture as a factor in technology integration (Khlaif, 2018; Spiteri \& Rundgren, 2018).

With an emphasis on educators' training and their ability to recognise the possibilities in the technology's affordances (Callaghan, 2018; Fenton, 2017), the affordances themselves tend to be 'black boxed', or positioned as inherent qualities that should innovate teaching practices. However, research on iPads in practice illustrates that their role in the classroom is ambiguous and that iPads can acquire different meanings when they interact with pupils and materials (Burnett, 2017). While the impact of gamified apps relies on teachers' professional judgement about how to integrate such apps into other activities (Mikkelsen, 2018), iPad use might conflict with curricular policy, teachers' personal and institutional aspirations and notions about 'correct' teaching (Lynch \& Redpath, 2014). Underlying organisational considerations 'behind the scenes' are also relevant to consider when introducing iPads in school settings (Henderson \& Yeow, 2012). In descriptions of 'best practice', details about how teachers go about resolving these issues in their everyday classroom contexts are left out.

There is need for more contextualised 'on the ground' explorations of how technologies are actually used and organised by teachers in educational settings (Selwyn, 2010), rather than further discussions of the pre-ascribed educational value of devices' affordances (Bigum \& Rowan, 2004; Burnett, 2011; Wright \& 
Parchoma, 2011). Against this backdrop, the present paper aims to answer 'state of the actual' questions about what happens when a new digital device enters the classroom context, rather than looking for 'state of the art' results (Edwards, Nuttall, Mantilla, Wood, \& Grieshaber, 2015). Our research question states: How do teachers organise iPad practices in the classroom? By tracing the use of the new educational app, Dragon Minders (DM), in two first-grade classrooms, we illuminate how different settings produce different iPad practices and affordances.

\section{Classrooms as thingly assemblages}

We use the sociomaterial approach of Actor-Network Theory (ANT) (Latour, 2005) to gain a deeper understanding of the entanglement of humans and things and their associations in day-to-day practices. Within ANT, agency is not located as an inherent property of individuals or objects, but as a relational effect distributed across heterogeneous gatherings or assemblages of human and non-human actors (Law \& Mol, 2008). In order to understand what the iPad becomes and 'does', we therefore unravel the practices and material gatherings of the classroom, as well as the teachers and tools navigating within it.

There is need for a stronger awareness towards how teaching and learning happen in associations between humans and things (Cho, Cherniak, \& Jung, 2017; Fenwick $\&$ Richards, 2010). When a new technology enters a school, judgements are made about how it can be useful in the real context of the school and the classrooms in relation to its material characteristics and abilities (Bigum, 2012). A classroom may consist of several rooms, corridors, walls, norms, rules, and schedules, as well as the people and things inhabiting it, all of which may have implications for technology integration (Brooks, 2011; Burnett, 2011; Tondeur, De Bruyne, Van Den Driessche, McKenney, \& Zandvliet, 2015).

Educational technology has become 'black boxed', as it is surrounded by certain discourses and assumptions about its potential and 'affordances for learning'. Using ANT, we seek to unravel and re-assemble this 'black box' (Callon, 2007) and the 'iPad's classroomness' (Burnett, 2017). This involves denying the existence of any inherent or essential feature or characteristic of actors, such as technologies' potential and teachers' ability to 'tame' the technology. ANT focuses not on who acts, but on the associations between human and non-human actors. When 
associations are made, old ties may be broken, and unexpected novel effects are produced (Mol, 2010). The iPad's ability to act as an educational tool can therefore not be reduced to or prescribed by social or structural conditions of the classroom setting, but are instead performed by the relations in which it becomes immersed (Mulcahy, 2018).

New technology also challenges and disrupts the classroom assemblage. According to ANT, 'breakdowns' and disruptions are important to recognise, as they reveal complexities and tensions in the connections between people and things (Adams \& Thompson, 2011). Both the disruptions and the possibilities that devices bring about are results of a continuous interplay between the limitations and opportunities provided by technology and the educational setting (Edwards, 2012). Against this theoretical backdrop, we explore how the iPad 'acts' in two classrooms; enactments that can be viewed as a fluid, heterogeneous assemblage of human and non-human actors (Law, 2002). The iPad practices that emerge are thus viewed as relational effects of these actors' continuous interplay and negotiations.

\section{The setting}

The empirical basis for this paper is the introduction of the new app, Dragon Minders (DM), developed for early education literacy training and special needs education by a small private company in Northern Norway. DM is a gamified 'edutainment-app', intended to supplement early literacy and working memory training. The introduction of the app was a result of the work of this private company, and the developers selected schools who responded to an invitation to be part of this specific project. As iPads are not ordinarily used as tools in Norwegian classrooms, and because this particular app was unique at the time, we elaborate on this as an example of how different iPad practices emerge in different classroom settings.

Before DM was launched on the App Store and Google Play, the developers provided it to two primary schools free of charge in exchange for the teachers' feedback. The company has continued to introduce the app into several schools since our study was conducted. In this study, we follow the introduction and use of the app in the first two schools invited to participate, here named school A and school B, from March to October of 2017. School A is a medium-sized city school 
located near the authors' place of work. School B is a smaller school located in a different county in the northernmost part of Norway.

\section{Research methods}

We applied a qualitative case study design (Yin, 2014) with an ethnographic approach (Gobo \& Marciniak, 2016) to gain deeper insight into the inner workings of each school and their everyday classroom contexts as DM was introduced and practised. We used a variation of qualitative methods (Denzin, 1970; Thagaard, 2009), supporting a multi-layered view of the empirical field. This particular paper is based on analyses of 16 hours of classroom observations and interviews with six teachers.

As the schools were located in different counties and each organised their use of iPads differently, the empirical work was adjusted to the context of the research field. In school A, the iPad was used routinely for about two hours a week. Classroom observations were conducted during these hours over the course of four weeks, capturing the total use of DM in this school during this period. In school B, the iPad was used throughout the school day, and the empirical data were gathered by following one teacher over four days: two days in March 2017, and two days in October 2017. While the methodological approaches of the two schools differed slightly, the aim was not to compare the effects or learning experiences of the app itself, but, rather, to enrich insight into how teachers organised iPad practices in two different classroom settings. Hence, the study foci are the teachers, their practices, and the movement and use of tools.

The classroom observations were initially non-participatory. After of the first few observation sessions, we engaged in a more participatory research role- - serving, in a sense, as teacher assistants - to gain a more natural position in the classroom and the teachers' everyday school routines. Supplementary unstructured field notes were also used to remember and record contextual information, such as teacher behaviours and activities, both within and outside the immediate classroom setting. Towards the end of each set of observations, interviews were conducted with three teachers from each school who had practised DM in their teaching. The interviews comprised a combination of semi-structured and open-ended questions. In school A, the interviews were conducted in June of 2017, after the teachers had been using 
the app routinely for about four weeks. In school B, two of the interviews were conducted over the course of the fieldwork undertaken in March and October of 2017, when the teachers had been using DM for four and eight months, respectively. The third interview was conducted over the phone to include a teacher who had participated in the initial introduction of DM, but who had later moved to work in a different school. The participants comprise the total number of teachers who practised DM in both schools. The interviews lasted between 40 minutes and one hour and revolved around the teachers' experiences of using iPads and DM in their classrooms. The interviews and observations were transcribed and anonymised before analysis.

\section{Analysis}

We conducted separate inductive analyses of the interviews and the observations, in which empirical descriptions took on a privileged role in relation to pre-existing categories and explanations (Latour, 2005). The data were analysed using a digital data and project management software for qualitative research (NVivo). Statements about the tools and practices used were first coded separately. We then applied queries across codes to trace the connections between tools and practices. These connections, based on observations and interviews, then became constructions of what Adams and Thompson (2016) describe as post-human anecdotes, recreating everyday situations and narratives in which both human and non-human actors had a say. In these anecdotes, we are able to trace how the iPad and its affordances are enacted in different ways in two classroom settings.

\section{Findings}

In the following, we will analyse the planning and practice of iPad use in schools A and B. The analysis is structured as anecdotes about iPad use from each school, telling the story about how the iPad use was planned and practised in the classroom setting. These are followed by discussions of how each classroom enacts different assemblages in which the iPad is made to act.

\section{School A}

School A had ten iPads available and approximately 40 first-grade pupils divided into two groups. The teachers had not previously used their iPads at the time DM 
was introduced, but their special education teacher expressed an interest in the app after meeting the developers and requested it for the school.

The iPads were shared among all the teachers in the school and were stored in a secured portable charging station (the iPad trolley) in the teachers' offices. The teachers could book the iPads for a maximum of a two-week period using the school's online portal and had to fetch a key from school reception to unlock the trolley before every use.

\section{Planning the iPad practice}

To provide all pupils the opportunity to use DM, the teachers in school A used the iPads during 'station work': an established routine that took place during the two first lessons of the day on Mondays and Fridays. During these lessons, the pupils were divided into groups of five that rotated through different 'work stations' every fifteen minutes. The station work was organised to free up time for guided reading, as the teachers worked with one reading group each in a separate room while teacher assistants supervised the pupils in the classroom. This practice allowed the teachers to focus on smaller groups sorted according to reading level. As the pupils were already divided into groups of five, the teachers could easily organise two iPad stations, one in each classroom, and the pupils were able to use the app for about 15 minutes each.

As the teachers were asked to employ the DM app in their teachings, they needed to engage in some practical considerations to distribute the limited number of iPads to the pupils. According to the teachers, iPads are self-governed and do not require much teacher involvement. The iPad fit well into the station work, as it became part of a self-governed learning environment that enabled the teachers to carry out guided reading, which they considered to be one of the most important practices of their early literacy training.

Due to the teachers' limited access to technology, their notions of iPads and literacy training and how they organised the classroom, the iPad was used as an 'add on' to the guided reading activity. However, the teachers' decision concerning how to integrate the app was not merely the result of an inability to maximise the iPad's potential, but of how the devices, the pupils, and the teachers themselves moved and oriented themselves in the classroom. 


\section{Moving the iPad}

In the teachers' office, one of the teachers is standing next to the trolley, checking that the app works on all ten iPads. The iPads have simple smart covers that can be folded back. While one teacher takes the trolley to the elevator, the other teacher and one of the teacher assistants take the stairs to the first-grade classrooms, which are located on the ground floor of the school. The teacher with the trolley tells me to go ahead, as the elevator can take a while, raising her eyebrows a little bit. When I ask her if the trolley is heavy, she answers that it is nothing compared to the laptop trolley, which is too heavy for her to push alone.

The trolley is placed in the corner next to the blackboard in one of the classrooms. The teacher assistant puts five iPads on a group of desks clustered together and the remaining five in the classroom next door with the other teacher. Meanwhile, about 20 pupils enter the classroom and gather in a horseshoe formation on benches in front of the blackboard, where the teacher sits in the centre. They complete a brief morning ritual and the teachers relay instructions for the workstations.

- $\quad$ Observation March 16, 2017.

\section{The practice}

The teacher tells the pupils to be careful with the iPads, not to walk around with them and that they are only to use the DM app. If the pupils open other applications, they lose their iPad privileges. The pupils quickly assemble in their respective groups on tables spread around the classroom. The teacher asks the pupils in the first guided reading group to bring their 'red folders' and follow her into the next room.

The pupils open their iPads and start playing on their own. The assistant seldom checks up on the pupils who are playing on the iPads and, instead, focuses on supervising the other stations with mathematics and writing exercises. When she does approach the iPad group, it is to ask the pupils to turn the volume down or to check whether they have opened other applications. When it is time to switch groups, she claps her hands to get the pupils' attention and asks them to put the iPads down and move to the next station. The next group of pupils then continues where the first pupils left off in the DM app. 
Near the end of the lesson, the pupils are asked to help clean up their current stations, place the iPads face down on the table, and put their red folders in their backpacks. When they finish cleaning up, they go out into the hall to get dressed for recess. While one of the teachers helps the pupils dress, the other teacher collects and stacks all the iPads on a desk, puts them back into the trolley and connects them to their chargers one by one. When the pupils are dressed and on their way outside, the assistant takes the trolley back upstairs via the elevator.

\section{The iPad assemblage}

This routine repeated itself for all four weeks of observing DM use in practice. First, the iPads needed to be moved to the classroom, which involved a string of actions and materials before the devices reached the desks. After booking and unlocking the iPads, the teachers used the elevator to move them downstairs. In the interviews, one of the teachers mentioned that, if the elevator was out of order, they needed to unplug each iPad and carry it downstairs. At that point, she argued, she might as well forego the iPad altogether and instead bring some worksheets or use the books the pupils already had in their backpacks. The teachers repeatedly described the process of transporting the few devices available as cumbersome and did not seem to consider the iPad to be accessible or easily moved.

As the pupils got started on their workstations in the classroom, the teachers moved to separate rooms with the other pupils and their red folders. The folders contained the pupils' individual textbooks (which were adapted to their reading level) and were described by the teachers as being essential for the smooth running of everyday operations. The folders also contained weekly schedules and important messages from parents to teachers (and vice versa). The folders were available in the pupils' backpacks at all times, making transitioning between stations effortless. The pupils' paper folders could thus also be considered a 'technology' in the classroom and as being parallel to the iPad, as they offered many of the same 'affordances': the folders were light and easy to carry around, held many important documents and individualised learning materials, and established connections between school and home. As seen here, the folder gained a more significant role in the classroom, as it was always moving with the pupils. 
The iPad station was the only station in which the pupils did not tidy up after themselves, as the iPads were primarily handled by the teachers. As iPads are expensive and the simple covers provided little protection against falls or scratches, the teachers did not want the pupils walking around with them. The sound effects from the app also became an issue, and the teachers eventually started to hand out headsets to avoid the app becoming too distracting to other pupils. The iPad and the app, thus, became an added practice in the classroom and in the everyday transitions between classes and recess, constantly requiring extra assistance and equipment in order to work.

These tracings of how iPads were organised and practised in the classroom setting illustrate the sociomaterial fabric of the classroom into which the iPad enters. As the app was introduced, the teachers made practical and professional judgements concerning how to make the tool useful, given the limited number of available devices. The devices themselves also needed to move and find a place in the classroom, as they entered a web of choreographed routines and movements of things, teachers, and pupils. Specifically, the devices became isolated as 'the iPad station': a block within a self-governed classroom, a potential distraction, and disassociated from the teachers. While one could describe this approach to iPad use as merely an 'add-on' to traditional teaching, the teachers continuously explained how they saw no better way of organising the iPad practice with limited resources.

\section{School B}

When DM was introduced to school B in 2016, the school had recently implemented a large-scale iPad initiative. All pupils and teachers from first to tenth grade were provided with their own personal iPads as primary educational tools. The school had arranged for the pupils to use the iPads both in school and at home by having the pupils' parents sign liability forms. The pupils were, thus, responsible for keeping the iPads charged and safely stored. Furthermore, the classrooms were equipped with Apple TVs, and the school had improved its WiFi connection.

The school had spent significant resources on the devices, apps, and a learning management system (LMS) developed for iPads, and DM was welcomed as a free addition to its 'app repertoire'. The first-grade pupils had used the app for a few 
months at the time of the fieldwork, so the iPad practice was already embedded. The following excerpt describes the more or less stabilised iPad practices.

\section{The classroom}

I am greeted by the teacher, sitting by her desk with an iPad. The classroom is structured by pupils sitting in pairs on rows of desks and a blackboard on the front wall behind the teacher. Each pupil has an iPad with a thick and solid casing and a backrest to allow the iPad to stand upright. Some of the pupils have their own headsets plugged in. If there is too much noise from one of the iPads, the teacher corrects the responsible pupil, saying, "Those who do not have headsets are not allowed to have sound". A few pupils are walking around and looking at one another's screens or walking up to the teacher for help with pop-up notifications. A teacher assistant is strolling between the desks, observing and guiding the pupils in their iPad use.

The blackboard has an Apple TV connected to it, which is used as a presentation tool onto which both teachers and pupils can transfer their iPad display through Bluetooth. Each Apple TV has its own access code. On one of the walls, I see laminated paper sheets with 'iPad Rules': 'We sit still at our desks when we work with the iPad', 'We always carry the iPad with both hands and walk carefully', and 'We put the iPad back in its place and charge it'. While these rules suggest that the iPads, for the most part, stay still, I observe that the classroom is quite dynamic and that the pupils move together with their iPad when they need to. The teacher allows the pupils to move around if they are helping each other with assignments.

One of the pupils comes up to the teacher because he has left his charger at home and his iPad is low on power. The teacher arranges for him to borrow a charger from another pupil and moves his desk next to the wall, where there is an outlet. She asks if anyone else has forgotten their charger and notifies them that "forgetting your charger is the same as forgetting your textbook".

Near the end of the lesson, the teacher turns off the Bluetooth on her own iPad, explaining that she does this to prevent the pupils from sendingmessages and pictures via Airdrop while she is away from the classroom. Such behaviours are also sanctioned by the short-term removal of iPad privileges. 


\section{The practice}

The teacher asks the pupils to go get their headsets, which are stored in the shelves at the back of the classroom. When they return to their desks, the teacher tells them to take their iPads out of their backpack, put away their drinking bottles and leave their iPads on their desks, screens down, until further notice. The teacher gives this instruction by saying 'Apple up', referring to the Apple logo on the back of the iPads (even though the logo does not show because of the casing).

When the pupils are required to log on to a website with learning resources, some of the pupils bring the iPad over to the blackboard to see the website password, which is written on a piece of paper. The teacher tells them which exercises to do on the website, and the pupils work on their iPads individually while the teacher walks among them to supervise.

Next, the pupils listen to an e-book with headsets on their own iPads, and the teacher asks them questions about what they have read afterwards. When there are about ten minutes left in the lesson, the pupils who have finished their online exercises are allowed to 'feed the dragon', referring to the DM app. Most of the pupils play DM in the time remaining before recess. When the lesson ends, some of the pupils are about to wrap up their headsets and put their iPads in their backpacks, but the teacher notifies them that they will continue using the iPads after recess, so they can keep them on their desks.

- Observation October 10, 2017

\section{The iPad assemblage}

The first encounter with the classroom setting in school B illustrates how the iPad was interwoven into everyday activities through both the material object in the room and the teacher's actions. The teacher's instructions appeared well incorporated, and the laminated rules on the wall suggested some permanence of practice. The Apple TV, the solid casings, and the iPad in the backpack were all actors supporting the entangled movements of devices, pupils, and digital resources across the classroom space. 
The iPads were easily accessible from the pupils' backpacks and were handled by the pupils themselves. The teacher established routines for the pupils to bring their iPads and other necessary equipment to their desks, thus removing risk factors such as water bottles, as well as routines for putting the iPads down. Even the Apple logo had made its way into the teachers' vocabulary for classroom management. While the iPad had prompted some new routines, the teacher continuously drew analogies between the iPads and books in the classroom when referring to the pupils' responsibility for the device, and seemed to view the device as any other educational tool.

The second observation study illustrates how the iPad was organised and employed for many different purposes in the classroom (Burnett, 2017): textbook, presentation tool, audiobook, worksheets, and something in between play and learning. While the DM app played a very small role in the pupils' everyday practice, it was also embedded into the overall iPad practice, as illustrated by it having its own instruction: 'feed the dragon'. According to interviews with the teachers, apps such as DM had replaced many of the extra worksheets and books that they would have previously handed out to fill time gaps between lessons and before recess.

When discussing the practice of using apps in the classroom, the first-grade teacher stressed that she always reviewed and played through the apps herself before she employed them in her teaching, sometimes using examples from the apps she knew the pupils would recognise in her lectures. All the teachers who participated in the study from school B emphasised the level of individualised teaching the apps supported. By allowing the pupils to play with apps from time to time, the teachers ensured that all pupils were working at their own pace and according to their own level.

The teachers further underlined the advantages of staying connected to the pupils outside of school. The pupils played DM at home before school, and the teachers often had the pupils do their reading exercises at home and then hand them in as audio files through their LMS app. The teachers could then give their pupils online feedback when they had time available, rather than having them read one by one in the classroom. These practices freed up time to focus on other activities during school hours. The LMS also functioned as the primary communication means 
between school and home: a place for the pupils to ask questions and hand in their homework. A fourth-grade teacher also mentioned the positive impact of conducting vocabulary tests in the LMS, rather than keeping track of stacks of paper.

The anecdotes from school B illustrate how the iPad interacted with the classroom in different ways. While one could argue that the iPad was adopted merely as a replacement for established practice, as the pupils still worked individually at their own desks in a 'traditional' classroom structure, it also renegotiated and renewed routines and practices and replaced a range of paper-based learning materials. Allowing the iPads to move between school and home further opened up new ways of carrying out early literacy training, which freed up time and resources in the classroom.

However, the iPad practice was not seamless, and challenges arose along the way. When pupils needed to charge their iPads, they moved desks and chairs to the nearest outlet. The pupils had also discovered ways to send messages and images using Airdrop, so the teacher implemented new rules and sanctions and developed a habit of switching off her Bluetooth before leaving the classroom. Furthermore, the iPad challenged the limits of the teachers' work hours, making them available to help pupils with homework and answer questions from parents after school. While the teachers themselves described these possibilities as being advantageous, they also had to set their own boundaries for when they were 'on duty'.

\section{Discussion}

Through the use of post-human anecdotes and by adopting an ANT approach, this paper describes how iPads become interwoven into the sociomaterial fabrics of two classroom settings. Our research question was: how do teachers organise iPad practices in the classroom? When teachers are introduced to a new digital tool, they

make both practical and pedagogical judgements about its role in their teaching practices and classrooms. In other words, new tools do not enter into a vacuum; rather, they interact with the teachers, the pupils, and the classroom environment.

In school A, the gamified app fit well into existing literacy training, as it freed up time for the teachers to focus on smaller groups: a practice also observed in previous research on iPad adoption (Lynch \& Redpath, 2014). Given the teachers' 
judgements and practical considerations in their sociomaterial context, this practice was the result of an interplay between access to technology, the teachers' professional judgements, and their notions concerning the tool's role in the classroom. The iPad was enrolled (Callon, 2007; Burnett, 2017) into the classroom choreography, and access to the devices, the guided reading activity, the setting of time limits, and the groupings of desks, were all actors that helped form the practice.

The iPad's 'affordance' as a mobile device was limited, and the teachers in school A did not consider the devices to be easily portable or accessible for classroom integration. Overall, mobility is considered the iPad's most distinctive feature (Henderson \& Yeow, 2012). Mobile technologies are assumed to foster significant pedagogical shifts due to their portable, intuitive, and flexible characteristics (CheeKit et al., 2010), and their ability to sustain learning environments regardless of place (Henderson \& Yeow, 2012; Martin \& Ertzberger, 2013). There is also a strong discourse surrounding 'mobile learning', loosely defined as learning through portable devices with internet connection capabilities (Wang, Wiesemes, \& Gibbons, 2012), and its potential to change classroom practice (Jahnke \& Kumar, 2014).

Exploring the 'state of the actual', the findings presented in this paper challenge the extant mobile learning discourse. In line with previous research on mobile devices and practices, they show that mobility is not an inherent characteristic of technological devices, but a non-human agency performed through the connections and interactions of a web of actors (Hemment, 2005; Thompson, 2016). In school A, the (im)mobility and accessibility of the iPads were enacted by the booking system, the trolley, the elevator, and the teachers, like 'knots' tying together a route of passage. As the iPads became 'iPad stations', they were enacted more as fixed desktop devices, moving almost exclusively between the desks and the trolley. In the sociotechnical 'breakdown' involving chargers in school B, the teacher relied on available wall outlets and refurnished desks and chairs to allow the pupils to charge their iPads. Occasionally, the classroom also required the pupils to move with their iPads: for instance, to type in a password written on the blackboard. When equipped with an Apple TV, the classroom allowed the iPad display to move to the blackboard from the pupils' desks. The iPads' movements in the classroom were, thus, continuously enacted by the intermeshing of human and non-human actors. 
The teachers also seemed to take part in an ongoing negotiation between the affordances of iPad and paper. Considering the iPad's route of passage from the trolley into the classroom in school A, they preferred paper for organising and assembling the mobility of materials and pupils in and between classrooms. This preference was well illustrated by the red paper folder. While the folder and the iPad offered many of the same affordances, their differences in use lay in how they were organised or enacted in the classroom's sociomaterial arrangements. By contrast, in school B, the scale of the iPad implementation allowed the iPads to replace the different roles enacted by the red folders in school A.

While the teachers in school B may not have exhausted the possibilities of handheld devices, they put more emphasis on how the iPads simplified and altered everyday tasks and routines. Like Henderson and Yeow (2012), these teachers saw the iPad as a 'simple sort of solution' (p. 84) and contextualised it as any other learning material, rather than as a tool to increase learning. However, iPad use in school B was not without tensions and paradoxes (Edwards, 2012; Jarvenpaa \& Lang, 2005): it created the need for new solutions and challenged the limits of teachers' work hours. Bringing iPads into the classroom setting created a mishmash of hindering and fostering mobile practices, illustrated well by the many roles of the Bluetooth button (Thompson, 2012): On one hand, Bluetooth allowed the teacher to transfer her iPad display to the blackboard and interact in real-time with her pupils; on the other, she turned it off to prevent Bluetooth sharing from being a disturbance outside of the classroom.

The schools in this study obviously differ regarding access to iPads. However, these findings show how the iPad's (im)mobility within and outside the classroom is assembled and coproduces classroom practices in both cases. Both classroom settings illustrate the ambiguity of technology in use and how its affordances are enacted in situ rather than being inherent to the devices.

\section{Limitations and future research}

This study is limited to a few first-grade classrooms and teachers, and iPad use will likely differ among older pupils. As we did the research following the initial implementation of iPads in school B, some early adoption processes may have been 
overlooked, and following iPad integration from the start could have generated more information and nuances about the iPad integration process.

Others have suggested sociomateriality as an appropriate theoretical construct to inform situated research on learning practices and technologies (Johri, 2011; Sørensen, 2009), and, according to Thompson (2016), place seems to play a significant role in mobile learning practices among adults. This was something we did not have the opportunity to explore further as we did not follow the iPad outside the school context. For future research, it would be interesting to explore ANT as an approach to understanding how mobile learning processes are enacted beyond the immediate classroom setting and with more emphasis on the pupils.

The aim of this study was to produce detailed descriptions of teachers' work processes when integrating a new digital tool into their classrooms. An ethnographic case study of two highly varied classroom settings accomplished this to a certain degree and could influence how practitioners, researchers, and policy makers reflect on technology integration in schools.

\section{Conclusion}

Exploring how iPads are organised by teachers in two classroom settings illustrates how the iPad's role and 'affordances' become embedded in fluid and intertwined connections between social and material actors in the classroom, such as teachers' notions of the tool and additional digital and non-digital resources. 'iPad practice' is performed in these connections and the ways in which they are organised and assembled.

While previous research has focused on how the iPad as a mobile and interactive device should innovate teaching and be fully utilised by teachers, we have challenged the very notion of the iPad having inherent qualities to improve teaching. In this study, mobility emerged not as an affordance of a single device, but, rather, as a material agency produced in heterogeneous assemblages of human and non-human actors. Moreover, the ways in which the iPad was organised and interacted with teachers' practices were largely contingent on how (im)mobility, access and ownership were enacted by the classroom assemblage. 
The findings from these two schools provide knowledge of how different settings produce different iPad practices, and unpacking the enactments of the iPad gives rise to a range of social and material relations and tensions in the classroom that are often overlooked. While the iPad became a closed off activity and immobile tool in school A, it permeated and replaced a wide range of practices in school B. No actor can act alone (Law \& Mol, 2008), and, as these detailed descriptions of classroom settings and the movements within them show, actors need to be mobilised and interact with one another to enact iPad practices. Rather than asking about a tool's potential to enhance learning, we need to understand the sociomaterial relations within which the tool can contribute to learning practices. The iPad's (im)mobility also invokes challenges, routines, and new solutions, further strengthening the notion of educational technology as being ambiguous and intimately interwoven with the classroom setting. 


\section{References}

Adams, C., \& Thompson, T. L. (2016). Researching a posthuman world: Interviews with digital objects. London, England: Springer.

Adams, C. A., \& Thompson, T. L. (2011). Interviewing objects: Including educational technologies as qualitative research participants. International Journal of Qualitative Studies in Education, 24(6), 733-750. https://doi.org/10.1080/09518398.2010.529849

Hutchison, A., Beschorner, B., \& Schmidt-Crawford, D. (2012). Exploring the use of the iPad for literacy learning. The Reading Teacher, 66(1), 15-23. https://doi.org/10.1002/TRTR.01090

Bigum, C. (2012). Schools and computers: Tales of a digital romance. In L. Rowan \& C. Bigum (Eds.), Transformative approaches to new technologies and student diversity in future oriented classrooms: Future proofing education (pp. 15-28). Dordrecht: Springer.

Bigum, C., \& Rowan, L. (2004). Flexible learning in teacher education: Myths, muddles and models. Asia-Pacific Journal of Teacher Education, 32(3), 213-226.

Brooks, D. C. (2011). Space matters: The impact of formal learning environments on student learning. British Journal of Educational Technology, 42(5), 719-726.

Burnett, C. (2011). The (im)materiality of educational space: Interactions between material, connected and textual dimensions of networked technology use in schools. E-Learning and Digital Media, 8(3), 214-227.

Burnett, C. (2017). The fluid materiality of tablets: Examining 'the iPad multiple' in a primary classroom. In C. Burnett, G. Merchant, A. Simpson, \& M. Walsh (Eds.), The case of the iPad: Mobile literacies in education (pp. 15-29). Singapore: Springer.

Callaghan, R. (2018). Developing mobile teaching practice: A collaborative exploration process. Technology, Knowledge and Learning, 23(2), 331-350.

Callon, M. (2007). Some elements of a sociology of translation: Domestication of the scallops and the fishermen. In K. Asdal, B. Brenna, \& I. Moser (Eds.), Technoscience: The politics of interventions (pp. 57-78). Oslo, Norway: Unipub.

Chee-Kit, L., Peter, S., BaoHui, Z., Hyo-Jeong, S., Wenli, C., \& Lung-Hsiang, W. (2010). Leveraging mobile technology for sustainable seamless learning: A research agenda. British Journal of Educational Technology, 41(2), 154-169.

Cho, E., Lee, K., Cherniak, S. \& Jung, S. E. (2017). Heterogeneous associations of secondgraders' learning in robotics class. Technology, Knowledge and Learning, 22(3), 465-483.

Culén, A. L., Engen, B. K., Gasparini, A., \& Herstad, J. (2011). The use of iPad in academic setting: Ownership issues in relation to technology (non)adoption. In Old meets new: Media in education-Proceedings of the 61st International Council for Educational Media and the XIII International Symposium on Computers in Education, 2011 (pp. 555-563).

Denzin, N. (1970). The research act in sociology: A theoretical introduction to sociological method. London: Butterworths.

Edwards, R. (2012). (Im)mobilities and (dis)locating practices in cyber-education. In R. Brooks, A. Fuller, \& J. L. Waters (Eds.), Changing spaces of education: New perspectives on the nature of learning. London: Routledge.

Edwards, S., Nuttall, J., Mantilla, A., Wood, E., \& Grieshaber, S. (2015). Digital play: What do early childhood teachers see? In S. Bulfin, N. F. Johnson, \& C. Bigum (Eds.), Critical perspectives on technology and education (pp. 69-84). New York: Palgrave Macmillan US.

Falloon, G. (2013). Young students using iPads: App design and content influences on their learning pathways. Computers \& Education, 68, 505-521. 
Fenton, D. (2017). Recommendations for professional development necessary for iPad integration. Educational Media International, 54(3), 165-184.

Fenwick, T., \& Edwards, R. (2010). Actor-network theory in education. London: Routledge.

Fisher, B., Lucas, T., \& Galstyan, A. (2013). The role of iPads in constructing collaborative learning spaces. Technology, Knowledge and Learning, 18(3), 165-178.

Flewitt, R., Messer, D., \& Kucirkova, N. (2015). New directions for early literacy in a digital age: The iPad. Journal of Early Childhood Literacy, 15(3), 289-310.

Gasparini, A., \& Culén, A. (2012, September). Acceptance factors: An iPad in classroom ecology. Paper presented at the International Conference on E-Learning and E-Technologies in Education (ICEEE). Lodz, Poland.

Gobo, G., \& Marciniak, L. T. (2016). What is ethnography? In D. Silverman (Ed.), Qualitative research (pp. 103-152). London: Sage.

Guðmundsdóttir, G. B., Dalaaker, D., Egeberg, G., Hatlevik, O. E., \& Tømte, K. H. (2014). Interactive technology. Traditional practice? Nordic Journal of Digital Literacy, 1(9), 23-43.

Haßler, B., Major, L., \& Hennessy, S. (2016). Tablet use in schools: A critical review of the evidence for learning outcomes. Journal of Computer Assisted Learning, 32(2), 139-156.

Helleve, I. (2013). The networked classroom - Socially unconnected. Education Inquiry, 4(2), 395-412.

Hemment, D. (2005). The mobile effect. Convergence, 11(2), pp. 32-40.

Henderson, S., \& Yeow, J. (2012). iPad in education: A case study of iPad adoption and use in a primary school. Paper presented at the 45th Hawaii International Conference on System Science (HICSS). Maui, HI.

Hutchison, A., Beschorner, B. \& Schmidt-Crawford, D. (2012). Exploring the use of the iPad for literacy learning. The Reading Teacher, 66(1), 15-23.

Jahnke, I., Bergström, P., Mårell-Olsson, E., Häll, L., \& Kumar, S. (2017). Digital didactical designs as research framework: iPad integration in Nordic schools. Computers \& Education, $113,1-15$.

Jahnke, I., \& Kumar, S. (2014). Digital didactical designs: Teachers' integration of iPads for learning-centered processes. Journal of Digital Learning in Teacher Education, 30(3), 81-88.

Jarvenpaa, S. L., \& Lang, K. R. (2005). Managing the paradoxes of mobile technology. Information Systems Management, 22(4), 7-23.

Johri, A. (2011). The socio-materiality of learning practices and implications for the field of learning technology. Research in Learning Technology, 19(3), 207-217. https://doi.org/10.3402/rlt.v19i3.17110

Khlaif, Z. N. (2018). Factors influencing teachers' attitudes toward mobile technology integration in K-12. Technology, Knowledge and Learning, 23(1), 161-175.

Kongsgården, P., \& Krumsvik, R. J. (2016). Use of tablets in primary and secondary school - A case study. Nordic Journal of Digital Literacy, 11(04), 248-270.

Latour, B. (2005). Reassembling the social: An introduction to actor-network theory. Oxford: Oxford University Press.

Law, J. (2002). Objects and Spaces. Theory, Culture \& Society, 19 (5-6), 91-105.

Law, J., \& Mol, A. (2008) The actor-enacted: Cumbrian sheep in 2001. In C. Knappett \& L. Malafouris (Eds.), Material agency: Towards a non-anthropocentric approach (pp. 57-77). New York: Springer. 
Lynch, J., \& Redpath, T. (2014). 'Smart' technologies in early years literacy education: A metanarrative of paradigmatic tensions in iPad use in an Australian preparatory classroom. Journal of Early Childhood Literacy, 14(2), 147-174.

Martin, F., \& Ertzberger, J. (2013). Here and now mobile learning: An experimental study on the use of mobile technology. Computers \& Education, 68, 76-85.

Mikkelsen, R. (2018). iPad som verktøy i vurdering for læring [iPad as a tool for assessment of learning]. In L. B. Johanson \& S. S. Karlsen (Eds.), Restart: A veere digital i skole og utdanning [Restart: To be digital in school and education] (pp. 17-32). Oslo, Norway: Universitetsforlaget.

Mol, A. (2010). Actor-network theory: Sensitive terms and enduring tensions. Kölner Zeitschrift für Soziologie und Sozialpsychologie Sonderheft, 50, 253-269.

Mulcahy, D. (2018). Assembling spaces of learning 'In' museums and schools: A practice-based sociomaterial perspective. In Ellis, R. A. \& Goodyear, P. (Eds.) Spaces of teaching and learning: Integrating perspectives on research and practice (pp. 13-29). Singapore: Springer.

Murray, O. T., \& Olcese, N. R. (2011). Teaching and learning with iPads, ready or not? TechTrends, 55(6), 42-48. https://doi.org/10.1007/s11528-011-0540-6

Neumann, M. M. (2018). Using tablets and apps to enhance emergent literacy skills in young children. Early Childhood Research Quarterly, 42, 239-246.

https://doi.org/10.1016/j.ecresq.2017.10.006

Roschelle, J., Rafanan, K., Bhanot, R., Estrella, G., Penuel, B., Nussbaum, M., \& Claro, S. (2010). Scaffolding group explanation and feedback with handheld technology: Impact on students' mathematics learning. Educational Technology Research and Development, 58(4), 399-419.

Sandvik, M., Smørdal, O., \& Østerud, S. (2012). Exploring iPads in practitioners' repertoires for language learning and literacy practices in kindergarten. Nordic Journal of Digital Literacy, 7(03), 204-221.

Selwyn, N. (2010). Looking beyond learning: Notes towards the critical study of educational technology. Journal of Computer Assisted Learning, 26(1), 65-73.

Spiteri, M., \& Rundgren, S. N. C. (2018). Literature review on the factors affecting primary teachers' use of digital technology. Technology, Knowledge and Learning, 1-14.

Sørensen, E. (2009) The materiality of learning: Technology and knowledge in educational practice. New York: Cambridge University Press.

Thagaard, T. (2009). Systematikk og innlevelse: En innføring i kvalitativ metode [Systematics and sensitivity: An introduction to qualitative research methods]. Bergen: Fagbokforlaget.

Thompson, T. L. (2012). I'm deleting as fast as I can: Negotiating learning practices in cyberspace, Pedagogy, Culture \& Society, 20(1), 93-112.

Thompson, T. L. (2016). The making of mobilities in online work-learning practices. New Media \& Society, 20(3), 1031-1046.

Tondeur J., De Bruyne, E., Van Den Driessche, M., McKenney, S. \& Zandvliet, D. (2015) The physical placement of classroom technology and its influences on educational practices. Cambridge Journal of Education, 45(4), 537-556.

Wang, R., Wiesemes, R., \& Gibbons, C. (2012). Developing digital fluency through ubiquitous mobile devices: Findings from a small-scale study. Computers \& Education, 58(1), 570-578.

Wright, S., \& Parchoma, G. (2011). Technologies for learning? An actor-network theory critique of 'affordances' in research on mobile learning. Research in Learning Technology, 19(3), 247-258. https://doi.org/10.3402/rlt.v19i3.17113 
Yin, R. K. (2014). Case study research: Design and methods ( $5^{\text {th }}$ edn.). Los Angeles, CA: SAGE. 